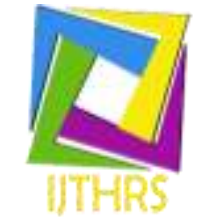

ISSN Print: 2686-5092

ISSN Online: $2685-3663$

Vol. 1, Issue 2, 2019, pp. 16-19

Received 2019-12-30

International Journal of Tourism, Heritage and Recreation Sport

http://ijthrs.ppj.unp.ac.id

email: pkphor@unp.ac.id

\title{
Management Of Sports Tourism Management In Mentawai Islands
}

\author{
Anton Komaini ${ }^{* 1}$, Endang Sepdanius ${ }^{2}$, Pudia M. Indika ${ }^{3}$ Hijriyantomi Suyuthie ${ }^{4}$ \\ Faculty of Sport Sciences, Faculty of Tourism and Hospitality, Padang State University, West Sumatra, \\ Indonesia \\ antonkomaini@fik.unp.ac.id, endangsepdanius@fik.unp.ac.id, pudia_dr@fik.unp.ac.id, \\ sitomtom@yahoo.co.id
}

\begin{abstract}
Mentawai Islands Regency is one of the areas in West Sumatra that develops sports tourism, among the tourism sports developed by the Mentawai Islands Regency are surfing (diving), diving (fishing), fishing (fishing), beach tourism, trekking along inland Mentawai forest. The purpose of this study was to determine the management of tourism sports in the Mentawai Islands District. This research is a type of descriptive research that aims to reveal the data encountered in the field. This research was carried out at the Mentawai Islands Regency Tourism Office. The sample in this study were 16 people. Variables that will be examined include organizing, promotion and infrastructure. The technique used to collect data is a Guttman questionnaire and interviews. The results of the study concluded that 1) The management of organizing sports tourism in the Mentawia Islands was in a fairly good category with an achievement rate of 59.38\%, 2). The promotion carried out by the Department of Youth Tourism and Sports in the Mentawai Islands District was in a good category with an achievement rate of $62.5 \%$. 3) The level of achievement of facilities and targets in the management of sports tourism in the Mentawai Islands is $40.18 \%$, this is included in the less category.
\end{abstract}

Keywords Management, Sport Tourism

This work is licensed under a Creative Commons Attribution-ShareAlike 4.0 International License.

\section{INTRODUCTION}

Sports tourism is a combination of two activities namely traveling and exercising. These two activities if carried out together will cause fun for the perpetrators of these activities. Sport is an important activity in tourism, and tourism and travel are basically associated with many types of sports. The specific influence of the two concepts varies according to the perspectives of stakeholders and their special interests in sports tourism. The diversity of interests in sports tourism raises important questions that must be addressed by academics and industry practitioners (Hinch and Higham, 2004: 18). Travel activities carried out for non-commercial reasons that are carried out actively and actively and participate in a relaxed and organized manner are the notions of sports tourism according to Standeven \& De Knop, 1999: 12.

Vacation tourism by doing activities as participants in the event or just watching it is often done by tourists in running sports tourism activities. The development of Sports tourism is influenced by several things, among others: 1) the increased need and physical fitness among the community, 2) the high interest of the community to actively participate in activities in tourist attractions, 3) the number of sports tourism events carried out, 4) Information technology is increasingly high, and 5) easy and cheap transportation access.

West Sumatra is one of the provinces that has experienced rapid development in sports tourism, a lot of sport tourism events held in the last few years include the Asian Cup Triathlon championship in Pariaman City, Tour de Singkarak, Mentawai International Pro Surf Competition, even paragliding Event Fly for Fun in Lake Maninjau, as well as the Harau Climbing Festival, as well as many other activities. Judging from the aspects of the natural potential and cultural richness of West Sumatra is very potential in developing sports tourism.

Mentawai Islands Regency is one of the areas in West Sumatra that develops sports tourism, among the tourism sports developed by the Mentawai Islands Regency are surfing (diving), diving (fishing), fishing (fishing), beach tourism, trekking along inland Mentawai forest. So that all forms of Pariwsata sports in Mentawai can develop well, of course there are many factors that influence them, including 
organizing, promotion, infrastructure, development programs, manpower in management. Thus, to get data and information that is close to scientific truth about the extent of the management of tourism in the Mentawai Islands, a research will be conducted to see the extent of these factors carried out by the local government.

\section{METHODS}

This research is a type of descriptive research that aims to reveal the data encountered in the field. As stated by Arikunto (2010: 3) that: "Descriptive research is research that does not intend to test certain hypotheses but only describes what they are about a variable, phenomenon or condition". Thus this research will reveal the data found in the field, namely the management of sports tourism in the Mentawai Islands Regency. This research was carried out at the Mentawai Islands Regency Tourism Office. The population in this study was 16 people. The sample in this study was taken by total sampling technique, thus the number of samples in this study were 16 people. The technique used to collect data is a Guttman questionnaire and interviews. Data analysis techniques are a very important part of research, because data analysis can provide meanings and meanings that are useful in solving problems in research. From the data to be obtained then analyzed. The analysis technique used in this research is descriptive.

\section{RESULT AND DISCUSSION}

\section{A. Result \\ 1. Organizing}

The data of this study consisted of: gross motor skills $(Y)$ as the dependent variable, playing environment $(X 1)$ and parenting style (X2) as independent variables. For each of the variables below, the average values, standard deviations, medians, frequency distributions, and histograms of each variable are presented.

a. Based on the research data for the Play Environment score, the lowest score was 23 and the highest score was 36 . From the data analysis the average price was 29.44 , Standard deviation was 3.31, Median was 29.5, Mode 32.

b. Based on the research data for parenting scores, the lowest score was 23 and the highest score was 36 . From the data analysis, the average price was 29.44 , Standard deviation was 7.07, Median 37.5, Mode 40.

c. Based on the research data for the score of Rough Motor Ability obtained the lowest score of 12 and the highest score 18. From the data analysis it is known that the average score is 17.33 , standard deviation is 1.64 , median is 18.00 , mode 18.

\section{Test Requirements for Analysis}

Test requirements analysis was carried out using the liliefors test to test the data normality. Does the population have normal or abnormal distribution. The criteria for normality testing are $\mathrm{Ha}$ accepted if $\mathrm{LO}<\mathrm{Lt}$ means that the population originates from normally distributed data and the data is abnormally distributed if $\mathrm{LO}>$ Then $\mathrm{Ha}$ is rejected. Based on the test results for Play Environment data (X1) is 0.1154 with a probability (sig.) Of 0.2000 . With $a>0.05$, it can be concluded that the data is normally distributed. The test results for parenting (X2) are 0.1272 with a probability (sig.) Of 0.2000 . With $a>0.05$, it can be concluded that the data is normally distributed. And the table above also shows that the test results for gross motor skills $(Y)$ are 0.1985 with a probability (sig.) Of 0.2000 . With $a>0.05$, it can be concluded that the data is normally distributed.

Based on the description above all the variables X1, X2 and $Y$ data are normally distributed, because each probability variable meets the criteria of $L o<L$ Tabel. It can be said that each data is spread normally or the population of the sample data is normally distributed.

\section{Testing of Hypothesis}

After the analysis of the requirements test is carried out and it turns out that all the scores for each research variable meet the requirements for further statistical testing, then the hypothesis testing is then carried out. In this study there are three research hypotheses, namely: (1). There is a significant relationship between the playing environment towards gross motoric skills of TK Pertiwi ll students, 2) There is a significant relationship between parenting style towards gross motor skills of TK Pertiwi II students, 3) There is a significant relationship together between the playing environment and Parenting style towards gross motor skills of TK Pertiwi II students. Obtained thit $=1.77>\mathrm{ttab}=1.75$ at the significance level $a=0.05$. Thus, Ha who said that there was a significant relationship between the playing environment and the gross motor skills of TK Pertiwi II students accepted, consequently $\mathrm{HO}$ was rejected.

This finding concludes that there is a significant relationship between the playing environment and gross motor skills of TK Pertiwi II students

Based on the results of data analysis, the achievement level of organizing (management) the management of sports tourism in the Mentawai Islands Regency is $59.38 \%$. According to Riduwan (2005: 89) the value classification between $41 \%-60 \%$ is in the classification of "sufficient". This means that the organization is done enough. Based on the results of interviews conducted by the author, obtained information that the management of sports tourism in the Mentawai Islands Regency has been running quite well, but it is only for surfing sports, whereas for other sports the management has not been running properly.

\section{Promotion}

Based on the results of data analysis, the achievement level of promotion in the management of sports tourism in the Mentawai Islands Regency is $62.5 \%$. According to Riduwan (2005: 89) the value classification between $61 \%-80 \%$ is in the classification of "Good". This means that the promotion is good, but only for surfing sports. Based on the results of interviews conducted by the author, obtained information that 
promotion in the management of sports tourism in the Mentawai Islands Regency, the government has collaborated with other parties, such as local media, radio, print media, the form of promotion carried out in the management of recreational sports is by held events, brochures, websites, print media and electronic media. The most effective form of promotion is used through websites

\section{Facilities and Infrastructure}

Based on the analysis of the data above, obtained the level of achievement of facilities and infrastructure in the management of sports tourism in the Mentawai Islands Regency by $40.18 \%$. According to Riduwan (2005: 89) the value classification between $21 \%-40 \%$ is in the "Less" classification. This means that the facilities and infrastructure for managing recreational sports in the Mentawai Islands District Tourism and Youth Tourism Office are still lacking. Based on the results of interviews conducted by the author, obtained information that the facilities and infrastructure in the management of sports tourism in the Mentawai Islands Regency has not been adequate, still need additional facilities and infrastructure, but to surf the facilities and infrastructure is quite good. The method of supervision carried out on recreational sports facilities and infrastructure is direct physical check in spaciousness.

\section{B. Discussion}

The organization is a body, a container, a place of collection of people who work together to achieve a certain goal. The role of the organization is to coordinate all activities in order to create a fabric of cooperation in groups to achieve a goal that is optimal achievement. Indonesia. Physical education and sports systems are management systems that are characterized by specific variables (activities, organizations, interactions, and goals) (Gabriel, 2013: 668).

Based on the results of research for the level of achievement of sub-organizational variables (management) obtained the level of organizational achievement (management) in the management of sports tourism in the Mentawai Islands by $59.38 \%$. in the "enough" category. This means that the organization has been done quite well, but it has not been maximized. Organizing in the management of sports tourism in the Mentawai Islands is already quite running, but still not optimal. For this reason, in the future, in order to become a good and healthy organization, it is necessary to have an organized and structured organizational structure and to carry out sports tourism in the Mentawai Islands to develop optimally, and other sports can be managed well.

Promotion is the activity of introducing products, convincing and increasing and returning target products to buyers in the hope that they will be moved and voluntarily ". According to Ali Hasan (2013: 603) "Promotion is a form of marketing communication activities that seek to spread information, influence, remind markets to be willing to accept, buy and be loyal to the products offered by companies". Promotion is an activity carried out to introduce a product or service to the public to be interested in buying it. In this research, the aim of the promotion is to attract visitors to do sports tourism in the Mentawai Islands. Based on the results of the study, the level of achievement of organizing (management) the management of sports tourism in the Mentawai Islands by $62.5 \%$, is in the classification of "Good". This means that the promotion is good, but only for surfing sports. Therefore, in the future the relevant agencies will be more active in promoting other tourism sports.

The development of sports tourism will run smoothly well, if supported by adequate facilities and infrastructure, both in terms of quantity and quality. It is not possible in a sports development to run well without the support of these facilities and infrastructure. According to Azhar (1993: 1) said what is meant by facilities and infrastructure are: "Means are tools that are used or needed in carrying out sports activities. While infrastructure is a place or building land that meets the requirements that are deliberately made so that it meets the requirements as a place for sports.

Based on the results of research the level of achievement of facilities and infrastructure in the management of sports tourism in the Mentawai Islands by $40.18 \%$. still in the lacking category. The facilities and infrastructure provided are still limited to surfing sports, while diving, snorkeling, fishing and trekking tours and others are incomplete, one of which is due to lack of budget. The existence of facilities and infrastructure is the backbone for the continuity of an activity. Means are all things that can be used as tools to achieve the objectives of an activity. Infrastructure according to is. Everything that is supporting the implementation of a process of activities. According to Suwantoro (1997: 22) tourism facilities are the completeness of the tourist destination areas needed to serve the needs of tourists in enjoying their tour.

\section{CONCLUSION}

Based on the results of the study, it can be concluded as follows:

1) Management of organizing sports tourism in the Mentawia Islands in the category is quite good with an achievement rate of $59.38 \%$,

2) Promotion conducted by the Department of Youth Tourism and Sports in the Mentawai Islands District is in the good category with an achievement rate of $62.5 \%$.

3) The level of achievement of facilities and targets in the management of sports tourism in the Mentawai Islands by $40.18 \%$, this is included in the less category

\section{REFERENCES}


[1] Hinch, Thomas and Higham, James. (2004). Sport Tourism Development. Channel View Publications An imprint of Multilingual Matters Ltd

[2] Standeven, J. and De Knop, P. (1999) Sport Tourism. Champaign, IL: Human Kinetics.

[3] Arikunto, Suharsimi. 2010. Prosedur Penelitian. Jakarta : PT Rineka Cipta

[4] Riduwan. 2005. Belajar Mudah Penelitian untuk Guru Karyawan dan Peneliti Pemula. Bandung : Alfabeta.

[5] Gabriel, Cucui Gheorghe, Alina, Cucui lonela. (2013). Research on the management of sports organizations Social and Behavioral Sciences 140 (2014) $667-670$
[6] Kotler. Philip. 2005. Pemasaran di Sektor Publik. Terjemahan dari M. Taufik Amir. Jakarta : Indeks

[7] Suwantoro, Gamal. 1997. Dasar-dasar Pariwisata. Yogyakarta: ANDI

[8] Winardi. 1992. Promosi dan Reklame. Bandung : Mandar Maju

[9] Ali. Hasan. 2013. Marketing dan Kasus pilihan. Yogyakarta : CAPS 